\title{
Strategic research on Living Theatre Serving the Society Based on Xingxiang Culture
}

\author{
Junzhi Zhao, Liyun Kong \\ Xingtai University, Xingtai, 054001, China
}

\section{Keywords: Living theatre; Social benefit; Research}

\begin{abstract}
As a regional culture, Xingxiang culture's birth is synchronous with that of Chinese culture. Meanwhile, it is an important and indispensible component of Chinese culture. The living theatre based on Xingxiang culture has risen like bamboo shoots after a spring rain and brought immeasurable benefit to the society in recent years. It is a kind of intangible cultural heritage and has profound connotation that other artistic forms cannot compare with.
\end{abstract}

Living theatre can be interpreted as an artistic form of stage plays performed on the stage. Its performing form is featured by diversity. Considering its types, opera, dance drama, drama and traditional opera are involved roughly. In history, living theatre used to be classical memory of people. In addition, living theatre has been an artistic form that shows uniform effect can be realized in the world for a long time. With respect to situations of modern society, living theatre brings immeasurable service strength to the society.

\section{Application of living theatre to real life}

Shakespeare said, 'The whole world is a living theatre'. Many people deem performance is fictitious and far away from reality and such a situation will make a number of people fail to distinguish the real world from a virtual world. However, performance of living theatre has been related to social life closely in modern life. Each person has different division of labor in society and plays a different role. Performance of living theatre develops rapidly in many developed countries and even becomes a huge industry. People's research on performance of living theatre not only involves it can cure people's mentality but also contains its wide application to commercial society.

A number of transnational enterprises pay attention to performance of living theatre so that they will invite professional actors to interact with their employees when training is given to them, including playing living theatre together with employees and simulating situations that employees may meet or have encountered. In such situations, employees can find solutions to problems, staff from the service industry can standardize their industrial quality via scenario simulation and commercial people may find ways to deal with things feasibly according to performance of living theatre. A great many of people in different industries may improve their work quality effective via performance of living theatre.

It is said that therapeutical effect of living theatre was found and used by people in ancient times. People could utilize performance of living theatre to enable others to generate basic concepts about cognition even in the period when primitive men lived. Additionally, they realized performance of living theatre would help with people's physical and psychological health and make people adapt to social life better. Actually, ceremonies carried out in various religions and even witchcraft are regarded as performance of living theatre, which is the earliest situation that people use performance of living theatre for treatment. At the end of the 1950s, some mental hospitals and clinics adopted living theatre and activities on stages and at theatres to help people having difficulty in learning because of related scholars' impacts. Lots of countries have developed activities and training in this aspect in modern society.

Performance of living theatre has entered education deeply in Taiwan. In detail, it is popularized at primary schools and is a basic skill that teachers must master. The reason for this is that research 
shows that people may use performance of living theatre to release their emotion, reduce their pressure and adapt to life, society and surroundings better no matter which status they stay in. Via playing roles in living theatre, they carry on their life orderly and happily.

According to experiments done in America, it is shown that frequent and purposeful organization about performance of living theatre for prisoners in prison will reduce the rate at which prisoners with propensity for violence to commit a crime again after being discharged from prison. Performance of living theatre is used for treatment at some places, including emotion adjustment and treatment about people's mental obstacle caused by limb deficiency or barriers. Performance of living theatre can also help us solve problems about social phobia and assist in lonely old people. It has obtained obvious effect in the foregoing problems. During performance of living theatre, people will have replacement of roles and transfer emotion, which will help them drain and balance their emotions to some extent. In doing so, treatment is realized.

\section{Current status and development trend of living theatre}

(1) Current status of living theatre

Recently, living theatre grows vigorously and develops with an unprecedented trend. Since the number of the audience increases, the living theatre industry is driven constantly. Another reason that cannot be ignored is that the number of theatres grows, which is helpful for development of living theatre to a large extent and whose impacts cannot be neglected but are critical. As for the market of Beijing living theatre, the reason why its spring comes is that one-hundred years' history of numerous theatres comes. Thus, many theatres encounter the phenomenon that schedule is too compact. This is the said era of 'speculation about schedule'.

Generally, there is much bitterness behind brightness. As the number of the audience grows, market of performance becomes more and more popular. As a result, rent of theatres rises constantly and schedule becomes compact increasingly. Thus, performing place is a practical and urgent problem that some private performing teams face with.

Regarding profitability, profitability of living theatre is low since living theatre still stays at the initial stage of marketization. Some people even say the industry of living theatre is an industry with low profits and its superficial prosperity is representation only. Actually, the number of living theatres that can obtain profits is small in the society. How to get profits effectively is also a difficult problem for the industry of living theatre at present.

(II) Development trend of living theatre

Nowadays, living theatre also develops and changes with development of the era, which is mainly reflected by the following aspects:

Firstly, performance of living theatre develops towards nationalization. Indeed, nationalization development trend of living theatre was obvious in the 1950s and 1960s. Some great achievements were obtained at that moment. This is also a correct direction towards which performance of Chinese living theatre will develop.

Secondly, performance of living theatre develops towards film and television. Film and television art is based on living theatre and its performing arts and techniques are also on the basis of the arts and technique used by performance of Chinese living theatre. However, because of rapid development of film and television art, it has owned perfect features and developed into independent types. Thus, it has its own artistic features. For this, it can be found that performing arts of performance of living theatre and the ones of film and television affect each other. When living theatre develops towards film and television, it will combine with authenticity and lifestyle of performing arts. Improvement in performance of living theatre will benefit a lot from this.

Thirdly, performance of living theatre develops towards diversification. It consults and absorbs features in many aspects and widely adopts essence of other kinds of art, such as song and dance, a martial art, rhythmic gymnastics and acrobatics, which can make living theatre more diversified and rich and adapt to demands of the era better.

Development tendency of modern living theatre is just as shown above. Its content becomes increasingly rich and involved content is wider and wider. This requires that actors should improve 
their professional level continuously. Only in this way can they satisfy social demands better.

\section{Features of the living theatre based on Xingxiang Culture}

Xingxiang culture itself is extensive and profound. As a unique national culture, it has experienced constant washing and baptism of history, which makes it more mature and more profound as well. Other cultures cannot compare with its unique historical feature. The living theatre based on Xingxiang Culture also has local features and peculiarity. Its features are mainly reflected by the following aspects:

(I) Themes are classical with some momentum

There are strict requirements for the living theatre with features of Xingxiang culture. Usually, selected themes are classical historical events. There is huge investment in making. All links are strict. In doing so, living theatre will have high quality, huge scale and some momentum.

(II) Huge cast

Because of a large scale of performance, people show much enthusiasm for participation. This is a good policy for the public and it can arouse people's enthusiasm for living theatre sufficiently to increase influence of living theatre.

(III) Content of living theatre can highlight local features and have profound cultural deposits

Performance content of the living theatre based on Xingxiang Culture is artistic reflection of local traditional culture and pays attention to highlighting local characteristics. With respect to innovation of our cultural industry, it also has classical creation. All of these shows are of profound connotation and have deep deposits. The audience will get significant influence and even enlightenment and education in such living theatres.

(IV) Flexible techniques of expression

The living theatre based on Xingxiang Culture owns flexible and changing forms. It has both entertainment nature and unique cultural and artistic color. When it shows content fully, it also brings dreamy feeling to people so that it seems that they are personally on the scene. Such a flexible form has unique charm and effect.

Living theatre has risen in China recently. Research on living theatre also increases gradually. The living theatre based on Xingxiang Culture sufficiently shows folk culture and re-display historical stories on the basis that its regional culture has been presented. This make the audience have profound comprehension about local customs, culture and history when they appreciate art.

In some scholars' survey and research, it is concluded that living theatre mainly has three features, including huge investment, good effect and high quality as well as large scale. What is it is the living theatre based on Xingxiang Culture? To sum up, it means various performing forms are used to perform content of living theatre, integrate with local cultural features and show unique folk customs to the audience on the premise that lots of high technology is used. In this way, it will give the audience profound impression as well as drive and advance local economy and many other aspects to some extent.

\section{Value of living theatre}

(I) Economic value

Economic value of living theatre can be divided into two aspects, i.e., direct economic value and indirect economic value. The direct economic value is reflected by the situation that living theatre can make local product structure more reasonable and enrich local resources. When the audience watches living theatre, their experience and feeling can be enhanced and local consumption level can be improved to some extent. Meanwhile, local incomes can be improved, development of the region can be driven and its popularity will be improved as well. The impact of indirect economic value is that local economy will be driven and developed by performance of living theatre so that economic level will be improved accordingly.

(II) Cultural value

Generally speaking, living theatre has its theme which is distinct and prominent. Usually, living 
theatre is shows via local historical events, myths and legends and local conditions and customs. Selection of such themes aims at advocating local culture, enhancing local people's consciousness about protecting intangible cultural heritage and making different regions communicate with one another better.

(III) Social value

Because of huge performing scale of living theatre, it has large social participation. Then, employment chances of local people increase to a large extent. Hence, they can win more incomes. At the same time, local residents' enthusiasm for their hometown also grows and their sense of pride rises as well. In this case, morality and quality of local residents will be improved.

\section{Social benefit brought by living theatre}

Social benefit mainly refers to benefit existing in the social field, which is mainly reflected by the following aspects, including construction of social system, impacts on people in life, urban construction, maintenance of social order and impacts of people's morality in society etc. In accordance with comparison with economic benefit, it is found that social benefit is hidden and intangible and its impacts are indirect and long-term. Social benefit of living theatre means social impacts and unexpected effect will be brought to local places to different degrees, including changes in popularity of local places, influence on protection about and improvement in local resources and effect on environmental protection. All of these are included in the range of social benefit. Besides, it will also have significant influence on local residents' living standard and quality.

\section{Conclusion}

Performance of the living theatre based on Xingxiang culture has full-bodied local features and unique charm and will bring hue economic and social benefit to local places. Thus, people should pay attention to protecting and advocating this kind of intangible cultural heritage and do not let this artistic treasure decline or disappear. There is a long way to go. Consequently, all people need work hard together.

\section{Reference}

[1] Hu Junxiu, Zhong Aiping. Comprehensive recreational center and urban society in modern times — taking Minzhong Park of Hankou (1919-1949) for example [J]. Gansu Social Sciences, 2010(05).

[2] Xu Rui. Sublimation of grand themes and pleasure of real life - thinking on two different orientations of creation about folk dances of Chinese ethnic groups via sampling analysis [J]. Journal of Beijing Dance Academy, 2006(03).

[3] Gou Qinghua. Research on feasibility of setting martial art performance teaching at sports colleges of China [A]. The fifth academic conference about sports science for national youth and the second memoir of high-end forum for Chinese sports doctors [C]. 2008.

[4] Hu Xingliang. From a close state to opening up and from realism to post-modernity — Research on the relationship between modern Taiwan drama and foreign living theatre [J]. Literature \& Art Studies, 2010(03).

This thesis is a task about social science development named Research on Improvement in Moral Education Level of Students Majoring in Performing Arts of Xingtai City in 2014 (task No.: XTSKFZ2014027) and task of People's Livelihood and Social Construction Research Base of Contemporary China in Hebei Province named Strategic research on Living Theatre Serving the Society Based on Xingxiang Culture (task No.: MSJD2014KTY039 ). 